Gönderim Tarihi: 21.08.2017 Kabul Tarihi: 05.01.2018

\title{
AN ANALYSIS OF THE ECONOMIC-ENVIRONMENTAL DIMENSION OF THE ORGANIZATION FOR SECURITY AND CO-OPERATION IN EUROPE: JUST A RHETORIC OR REALITY ${ }^{1}$
}

\author{
Hakan KARAASLAN* \\ AVRUPA GÜVENLIK VE İŞBİRLİĞİ TEŞKILLATI'NIN \\ EKONOMİ-ÇEVRE BOYUTUNUN BİR ANALIZİ: SADECE \\ BİR SÖYLEM Mİ YOKSA GERÇEKLIIK Mİ?
}

\begin{abstract}
This article aims to provide a critical analysis with regard to economic and environmental dimension of the Organization for Security and Co-operation in Europe (OSCE), namely 'Second Dimension of the Organization'. The article also aims to portray the OSCE's perceptions towards economic and environmental issues as well as their link to security. As a reflection of its comprehensive security approach, the OSCE is always concerned with the economic and environmental matters. This article argues that although the OSCE's involvement in the economic and environmental dimension reflects the Organization's comprehensive approach to security, economic and environmental dimension turns out to be the weakest dimension of the OSCE in terms of the overall contribution of the Organization to the efforts aiming at achieving comprehensive security. In other words, economic and environmental matters have remained secondary in comparison to the non-military issues in the field of human dimension and non-military aspects of the politico-military dimension within the OSCE context.
\end{abstract}

Keywords: Security, Comprehensive Security, Comprehensive Approach to Security, Organization for Security and Co-operation in Europe, Economic and Environmental Dimension.

\section{$\ddot{\mathbf{O z}}$}

Bu makale Avrupa Güvenlik ve İşbirliği Teşkilatı'nın (AGIT) ‘ikinci boyut” olarak adlandırılan ekonomi ve çevre boyutu ile ilgili eleştirel bir analiz ortaya koymayı amaçlamaktadır. Bu çalışma aynı zamanda AGİT'in ekonomik ve

1 This article is from unpublished $\mathrm{PhD}$ thesis of Hakan Karaaslan, 'The Organization for Security and Co-operation in Europe in the Post-Cold War Era: An Analysis of Its Comprehensive Approach to Security', submitted to the Middle East Technical University, 2015.

${ }^{*}$ Dr., Van Yüzüncü Yıl University, Faculty of Economics and Administrative Sciences, Department of International Relations, e-mail: hakankaraaslan@yyu.edu.tr. 
çevresel konulara olan bakışını ve bu konuların güvenlikle olan bağlantılarını da ortaya koymayı amaçlamaktadır. AGIT, kapsamlı güvenlik yaklaşımının bir yansıması olarak, ekonomik ve çevresel konularla her zaman ilgili olmuştur. $\mathrm{Bu}$ çalışma, AGİT'in ekonomi ve çevre boyutundaki dahlinin, Organizasyonun güvenliğe kapsamlı yaklaşımını yansıtmasına rağmen, ekonomi ve çevre boyutunun, örgütün kapsamlı güvenliğin gerçekleştirilmesindeki toplam katkısı göz önüne alındığında, AGİT'in en zayıf boyutu olduğunu iddia etmektedir. Başka bir ifade ile, insani boyut kapsamındaki askeri olmayan faaliyetleri ve siyasi-askeri boyut kapsamındaki yine askeri olmayan faaliyetleri ile karşılaştırıldığında, ekonomik ve çevresel konuların ikincil planda kaldığı görülmektedir.

Anahtar Kelimeler: Güvenlik, Kapsamlı Güvenlik, Güvenliğe Kapsamlı Yaklaşım, Avrupa Güvenlik ve İşbirliği Teşkilatı, Ekonomi ve Çevre Boyutu.

\section{Introduction}

The dominant approaches of the Cold War security studies adopted 'state' as the primary and central referent object of security in the Cold War period (Williams 2013: 3-4). In the discipline of International Relations, the main focus of security studies was to analyze and achieve 'state security' (Williams 2013: 7). State security basically refers to the protection of states' territorial integrity and the independence of states from any external danger or threat. In other words, state security includes the protection of its citizens, boundaries and national interests. In terms of state security, states heavily rely on their military power and they want to maximize their power in an anarchical international system. "Protecting the territorial integrity of the state is the traditional object of military security" (Buzan, Wæver and Wilde 1998: 70).

With the end of the Cold War period, a new security understanding has come to the fore in security studies beyond the traditional military and state-centric security conceptions of the Cold War. This new security thinking is mainly based on broadening and deepening of security studies. This new way of thinking on security as a concept has portrayed new referent objects rather than the state and new security dynamics and issues for security analysis. In the Post-Cold War period, security discussions have focused on the need of maintaining security studies beyond the traditional military and state-centric understanding of security (Gärtner and Hyde-Price 2001: 3-4).

The scope and nature of security studies has been significantly broadened, taking non-military aspects of security into consideration since the end of the Cold War. Security as a concept has been redefined encompassing the non-military issues beyond the traditional military 
domain (Mérand, Irondelle and Foucault 2011: 14-15). The origins of threats and challenges have been diversified, arising from different dimensions such as economic, environmental and societal in addition to the political and military domains. These new security threats and challenges started to gain importance and at the same time, they have been integrated into the security analysis. The new threat areas include the violation of human rights and fundamental freedoms, economic and environmental concerns, democracy, political stability, socio-political cohesion of societies, social and cultural issues, illegal migration, religion and identity issues (Gärtner and Hyde-Price 2001: 4-5), overpopulation, poverty, pandemics, organized crime, trafficking in human beings, drug trafficking, the proliferation of weapons of mass destruction and international terrorism" (Mérand, Irondelle and Foucault 2011: 14-15). Within this framework, security threats and challenges derived from economic and environmental factors have increasingly come into the agenda of security studies as well as states and international organizations. The OSCE has also focused on dealing with economic and environmental-based security risks and challenges within the framework of its second dimension, namely economic and environmental dimension.

This article, firstly, outlines the economic and environmental dimension of the Organization for Security and Co-operation in Europe (OSCE) in terms of the content, basic normative documents, structures and instruments on economic and environmental dimension. Secondly, the article focuses on the economic and environmental activities of the OSCE. Several security-related issues such as energy security, organized crime, corruption, good governance, migration, water management, climate change and transport security are included in the economic and environmental dimension of the OSCE. Finally, the article tries to provide a critical analysis to the OSCE's economic and environmental dimension.

\section{Economic and Environmental Dimension of the Organization for Security and Co-operation in Europe}

The OSCE always engages with economic and environmental issues as integral components of the Organization's comprehensive approach to security. The OSCE adopts an approach that close and effective cooperation and co-ordination on economic and environmental matters can make contributions to the maintenance of security, stability, peace and prosperity throughout the whole OSCE region (http://www.osce.org/eea).

With the signing of the Helsinki Final Act in 1975, the Conference on Security and Co-operation in Europe (CSCE) participating States 
established a close connection between security and peace and economic and environmental matters in European security. The CSCE participating States acknowledged that economic and environmental issues included in the second basket of the 1975 Helsinki Final Act are highly important and relevant for security and stability in Europe (Evers, Kahl and Zellner 2005: 26). In the Helsinki Final Act, the participating States strongly emphasized the importance of enhancing and maintaining co-operation on economic and environmental issues in promoting security and stability across the entire CSCE area. The economic and environmental issues constituted the 'second basket of the Helsinki Final Act'. After the end of the Cold War, with the rapid institutionalization process of the CSCE, transforming from a conference process to a full-fledged regional security organization under the United Nations Charter, the so-called second basket of the CSCE started to be called as the 'second dimension of the OSCE', or the 'economic and environmental dimension' (http://www.osce.org/secretariat/30348?download=true).

The OSCE performs a broad range of economic and environmental activities through its instruments and structures which focus on economic and environmental dimension of security. Work in the economic and environmental activities is an integral part of the OSCE's concepts of comprehensive, co-operative, common and indivisible security (http://www.osce.org/eea/96420).

The OSCE recognizes that healthy economic environment and economic prosperity in the participating States are of great importance for maintaining security and stability in the whole OSCE region. Therefore, the OSCE carries out a broad range of economic activities such as promoting good governance and transport security; dealing with organized crime, money laundering, corruption and the financing of terrorism; encouraging business development and promotion; and finally supporting the participating States in their efforts for facilitating better migration management (http://www.osce.org/what/economic).

"Recognizing the close connection between environmental issues and security", the OSCE also performs a wide range of environmental activities aiming at "restoring and maintaining a sound ecological balance in the air, water and soil". The main priority areas for protecting and improving environment are to achieve "sustainable use and sound management of natural resources" particularly promoting an effective water resource management; prevent soil degradation; promoting the safely disposal of hazardous waste; provide support and assistance for the maintenance of energy security dialogue among the participating States; and finally supporting the full and effective implementation of the 
'Environment and Security (ENVSEC) Initiative'. Furthermore, the OSCE has engaged in a series of initiatives with a view to raising the environmental awareness and encouraging public participation in environmental decision-making (www.osce.org/what/ environmental).

\section{A Normative Framework for the Economic and Environmental Dimension of Security}

Over the years, the OSCE has created a normative framework for the economic and environmental dimension. In the history of the CSCE/OSCE, there are two main milestone documents which have shaped the economic and environmental dimension of the Organization: 'The Bonn Document' (1990) and 'Maastricht Strategy Document for the Economic and Environmental Dimension’ (2003).

'Conference on Economic Co-operation in Europe' was organized in Bonn in 1990 with the participation of delegations including CSCE participating States representatives and business community members. The Bonn Conference produced 'Bonn Document' which established basic commitments and identified the main objectives with regard to the economic and environmental matters ('Document of the Bonn Conference On Economic Co-operation in Europe' 1990: 1).

The main objective of the Bonn Conference is to "provide new impulses for economic relations between participating States, in particular by improving business conditions for commercial exchanges and industrial co-operation and by considering new possibilities for, and ways of, economic co-operation". ('Document of the Bonn Conference On Economic Co-operation in Europe' 1990: 2). The Bonn Document states that "democratic institutions and economic freedom are key assets in facilitating economic growth and social progress". In the Bonn Document, "sustainable economic growth, a rising standard of living, an improved quality of life, expanding employment, efficient use of economic resources, and protection of the environment" were identified as the common objectives for the CSCE participating States. The participating States reconfirmed their strong belief on the necessity of enhancing co-operation among them in the fields of economics, science and technology as well as the environment. According to the Bonn Document, in order to promote close and effective economic cooperation, all CSCE participating States should be increasingly integrated "into the international economic and financial system" which functions in line with the rules recognized as internationally. The CSCE participating States agreed that it is highly important to realize more harmonized economic policies within the OSCE region in creating new and long-term 
economic opportunities aiming at strengthening economic relations between the participating States ('Document of the Bonn Conference On Economic Co-operation in Europe' 1990: 2-4).

In the Bonn Document, the CSCE participating States reiterated their strong belief that there is a close relationship between "political pluralism and market economies". In this respect, the main principles and commitments which provide guidance for the economic activities of the participating States and the Organization itself were listed ('Document of the Bonn Conference On Economic Co-operation in Europe' 1990: 4-5).

The Bonn Document includes a series of significant outcomes for the economic and environmental dimension of the OSCE ('Document of the Bonn Conference On Economic Co-operation in Europe' 1990: 6). The Bonn Document created the basic principles and commitments on economic and environmental issues which provide a basic guidance for economic and environmental dimension-related activities of the CSCE/OSCE. In the Bonn Document, the CSCE participating States declared their adherence to the free market economy principles which can pave the way for greater economic co-operation within the CSCE region. The Bonn Document put forward the main principles and commitments "designed not only to develop free and competitive market economies but also environmentally sustainable economic growth and development" ('The OSCE Concept of Comprehensive and Co-operative Security An Overview of Major Milestones' 2009: 4).

Evers states that the Bonn Document links economic freedom and environmental sustainability to basic European values such as democracy, the rule of law and respect for human rights. The main rationale of the Bonn Document is to "liberalize, open, and integrate the transitional economies into the international economic and financial system". Facilitating well-functioning market-oriented economies in the participating States remains as one of the most important priority areas for the OSCE (Evers 2011: 5).

The other important document on the economic and environmental dimension, 'the OSCE Strategy Document for the Economic and Environmental Dimension' was adopted by the participating States at the 2003 OSCE Maastricht Ministerial Council meeting. The Maastricht Strategy for the Economic and Environmental Dimension (EED) identifies the primary aspects of the OSCE's perceptions on economic and environmental issues. The Strategy Document also outlines a range of risks, challenges and threats to security and stability of the whole OSCE region generating from economic and environmental issues. The 
participating States are strongly convinced that maintaining co-operation on economic and environmental issues is the best choice for ensuring economic and environmental security (Evers 2011: 5-7). The Document also expresses that the main priority areas of the OSCE's economic and environmental activities are sustainable development, good governance, environmental protection and energy security (Brichambaut 2007: 190191)

In the OSCE Strategy Document for the EED, the participating States recognize the increasing significance of the economic and environmental dimension as an integral part of the Organization's co-operative and comprehensive approach to security and stability. They also acknowledge that "the major changes and developments in the economic and environmental situation in the OSCE region in the post-Cold War era have led not only to progress and achievements, but also to the emergence of new threats and challenges having an economic or environmental nature". The participating States declare their strong belief on the necessity of ensuring more active and efficient co-operation in order to deal with the existing and newly emerging security risks, threats and challenges derived from economic and environmental factors. It is agreed that promoting an effective co-operation in the economic and environmental fields can contribute substantially to the maintenance of security, stability, peace and prosperity across the entire OSCE region (http://www.osce.org/eea/20705?download=true).

The OSCE Strategy Document for the EED outlines a broad range of issues in the field of economic and environmental dimension. "Socioeconomic, demographic and environmental factors may affect security and stability" ('OSCE Strategy to Address Threats to Security and Stability in the 21st Century' 2003: 1). "Globalization, liberalization and technological change" have created a favorable environment and conditions for trade and economic growth and development. However, all OSCE participating States have not benefited equally from these global developments, which in turn create and deepen economic and social disparities between and within the OSCE participating States. "The growing openness of national economies and their greater exposure to external economic shocks and financial turbulence raises the challenge of managing globalization". Within this context, the OSCE aims at eliminating negative impacts of recent global economic developments on some participating States, thus contributing to making benefits available to all societies in economic and financial domains (http://www.osce.org/eea/20705?download=true). 
OSCE Strategy Document for the EED states that "deepening economic and social disparities, lack of the rule of law, weak governance, corruption, widespread poverty and high unemployment" are the main factors that cause serious security concerns and challenges and provides a favorable environment for the emergence of other global and transnational threats such as all kinds of trafficking, international terrorism, illegal migration, illegal economic activities, violent extremism and organized crime. Inter-State and intra-State conflicts in the OSCE region constitute serious obstacles to achieving regional economic cooperation and development and weakens "the security of communications and energy transport routes" ('OSCE Strategy to Address Threats to Security and Stability in the 21st Century' 2003: 3 and http://www.osce.org/eea/20705?download=true).

"Environmental degradation, unsustainable use of natural resources, mismanagement of wastes, pollution and ecological disasters resulting from natural causes, economic activities or terrorist acts have substantial negative impacts on the health, welfare, stability and security of all OSCE participating States as well as on ecological systems" (http://www.osce.org/eea/20705?download=true). "Problems of governance connected to these factors have a direct undermining effect and reduce the capacity in ensuring sustainable economic, social and environmental development as well as to effectively address economic and environmental challenges and threats to security and stability" ('OSCE Strategy to Address Threats to Security and Stability in the 21st Century’ 2003: 3).

The Maastricht Strategy for the EED outlines the OSCE's response to economic and environmental risks, challenges and threats to security and stability. The OSCE aims at responding to security threats and challenges related to economy and environment through encouraging further cooperation among the participating States in a range of areas and developing new actions and policies for "strengthening good governance at all levels, ensuring sustainable development in its all aspects and protecting the environment". In addressing economic and environmental threats and challenges to security within the whole OSCE region, the participating States are determined to take the activities and actions of other regional and international organizations into consideration with the aim of providing an added value and creating synergies (http://www.osce.org/eea/20705?download=true).

In order to effectively address threats and challenges in the field of economy and environment, the participating States declare their strong determination to maintain a broad dialogue on economic and 
environmental matters. Additionally, reviewing efficiently the implementation of economic and environmental dimension-related commitments and strengthening the Organization's capacity to offer assistance and expertise to its participating States remain as priority areas for the OSCE. Finally, Maastricht Strategy Document for the EED states that the OSCE will work in a close and active co-operation with other relevant regional and international organizations with a view to contributing to the facilitation of their expertise and resources which can be used for economic and environmental activities ('OSCE Strategy to Address Threats to Security and Stability in the 21 st Century' 2003: 7-8).

The OSCE participating States consider the adoption of the Maastricht Strategy Document for the EED as a significant step towards addressing economic and environmental threats and challenges to security and enhancing co-operation among the participating States in the economic and environmental issues. The full and effective implementation of the commitments and principles outlined in the Strategy Document makes a substantial contribution to the overall efforts of the OSCE for achieving comprehensive security across the entire OSCE region. Monitoring and reviewing regularly the implementation of the commitments on economic and environmental matters remains highly important objective for the OSCE (http://www.osce.org/eea/20705?download=true).

\section{Structures and Instruments in the Economic and Environmental Dimension}

There are significant structures and instruments in the OSCE, focusing on economic and environmental issues. 'The Office of the Co-ordinator of OSCE Economic and Environmental Activities' (OCEEA) within the OSCE Secretariat was established in November 1997. On the basis of the OSCE's comprehensive approach to security, the primary objective of the OCEEA is to "strengthen security and stability in the OSCE region by promoting international co-operation on economic and environmental issues among the participating States and their Asian and Mediterranean Partners"(http://www.osce.org/secretariat/30348?download=true and http:/osce.org/eea/43176).

The OCEEA's work is guided by the Economic and Environmental Committee of the OSCE Permanent Council (PC) and supported by the economic and environmental officers from the OSCE field missions. The OCEEA aims at identifying, monitoring and dealing with security risks, threats and challenges stemming from economic and environmental factors (http://www.osce.org/eea/43176). 
'Economic and Environmental Forum' (EEF), as "the main and the highest level annual meeting within the economic and environmental dimension of the OSCE" is organized by the OCEEA. Economic and Environmental Forum meetings have been organized annually since 1993, covering a broad range of specific themes in the economic and environmental fields. EEF is held on the basis of a chosen specific theme which is proposed by the OSCE Chairman-in-Office $(\mathrm{CiO})$ and adopted by all the participating States. The main objective of the EEF is to create a platform for international dialogue and exchange of information and views pertaining to the economic and environmental issues which are linked to security. EEF also engages in elaborating the specific recommendations and follow-up activities with a view to addressing threats and challenges stemming from economic and environmental factors within the OSCE region. The Forum is the main instrument of the OSCE in reviewing annually the implementation of economic and environmental commitments by the participating States.

EEF is held every year with the extensive participation of representatives from governments, civil society, business community, academia and other international organizations, with the purpose of promoting dialogue and consultations on how to respond to the security threats, risks and challenges deriving from economic and environmental matters (http://www-old.osce.org/eea/43229).

'The Economic and Environmental Sub-Committee of the Permanent Council' was created at the OSCE Bucharest Ministerial Council meeting on 4 December 2001. The Economic and Environmental Sub-Committee is mainly tasked to providing a platform for maintaining discussions and dialogue among the participating States on economic and environmental issues; offering recommendations to the Permanent Council concerning the projects to be implemented; and the future planning of the OSCE work in the economic and environmental dimension; and finally providing support and assistance for the arrangement of the Economic and Environmental Forum meetings (http://www.osce.org/eea/13910?download=true). In addition to these basic activities, the Committee evaluates "cross-dimensional issues with a strong link to economic and environmental aspects of security upon the request of the Chairmanship in consultation with the participating States" (http://www.osce.org/secretariat/30348?download=true).

'The annual Economic and Environmental Dimension Implementation Meeting' focuses on "the assessment of the implementation of economic and environmental commitments and identification of priorities for the future work of the Organization". The participants from a wide range of 
different fields including government officials, experts and academics "review and assess the implementation of the OSCE decisions and commitments in the economic and environmental fields" (http://www.osce.org/eea/84019) as well as "the economic and environmental activities and projects that have been undertaken over the past year" (http://www.osce.org/eea/96401). Implementation Meeting "provides a platform for dialogue and enhanced co-ordination and cooperation between OSCE participating States, OSCE Partner States for Co-operation, international and non-governmental organizations, civil society representatives as well as the OSCE Secretariat, field missions and permanent institutions of the Organization". Furthermore, the Economic and Environmental Dimension Implementation Meeting aims to identify the main challenges to economic and environmental security and providing recommendations for the Organization's relevant structures and institutions on how to effectively respond them (http://www.osce.org/eea/84019).

Finally, economic and environmental officers in the OSCE field missions, working in close co-operation and co-ordination with the OCEEA, make considerable contributions to the development and implementation of projects with the aim of assisting the participating States in their efforts for addressing, and dealing with the risks, threats and challenges to their security stemming from economic and environmental issues within the OSCE region (http://www.osce.org/secretariat/30348?download=true).

\section{Economic Activities of the Organization for Security and Co- operation in Europe}

The OSCE takes the view that economic prosperity is one of the most important factors in strengthening security and stability within the OSCE region. The OSCE, therefore, works to promote healthy and wellfunctioning economies and achieve sustainable economic growth and development in the participating States as a significant part of its comprehensive approach to security. Within this framework, the OSCE performs a wide range of economy-related activities aiming at supporting economic growth and development (http://www.osce.org/what/economic). These activity fields include: facilitating business and investment promotion; promoting good governance and fighting corruption; combating money laundering and the financing of terrorism; ensuring energy security; strengthening transport security; and finally achieving an effective migration management within the whole OSCE area. 
As a reflection of Organization's attaching importance to energy security, energy issues deserves a special attention among other economy and environment-related activities of the OSCE. Energy security is an integral component of the OSCE's comprehensive approach to security. Energy issues, including energy security, are placed under the OSCE's economic and environmental dimension (http://www.osce.org/eea/71241), because energy security has sorts of economic and environmental aspects. Energy security mainly emphasizes reliable supply of energy in affordable prices. However, energy security has different meanings for different actors. For producer or exporting countries, energy security is equal with the security of demand. For consumer or importing countries, energy security means the security of supply. Finally, for transit countries, energy security means both the security of supply and demand (Hakan Karaaslan, Interview with Richard Wheeler, Senior Programme Officer, Energy Security, Office of the Co-ordinator of OSCE Economic and Environmental Activities, Vienna, 14 November 2012). OSCE participating States are strongly agreed that ensuring energy security is highly important for facilitating sustainable economic growth and development and increasing social integration and living standards within the OSCE region. Facilitating "generalized access to energy at acceptable prices" is an essential condition for creating and maintaining wellfunctioning economies (Snoy 2006: 291).

"The political stability of a country is closely linked to the sustainability of its economic development". Uninterrupted and reliable access to energy resources is a necessary condition for achieving sustainable economic growth and development in a country. So, it means that reliable and stable energy resources are essential factors for political stability in a state. In this respect, with the purpose of promoting sustainable economic development as an important factor for the consolidation of political stability in a country, OSCE aims to contribute to the participating States' efforts for ensuring energy security (http://www.osce.org/serbia/16332).

Maastricht Strategy Document for the EED states that "a high level of energy security requires a predictable, reliable, economically acceptable, commercially sound and environmentally friendly energy supply, which can be achieved by means of long-term contracts in appropriate cases". In this respect, the OSCE participating States are determined to foster "energy dialogue and efforts to diversify energy supply, ensure the safety of energy routes, and make more efficient use of energy resources". They are also strongly determined to "support further development and use of new and renewable sources of energy" (http://www.osce.org/eea/20705?download=true). 
The OSCE PC adopted a 'Decision No.12/06 Energy Security Dialogue in the OSCE' at the 2006 OSCE Brussels Ministerial Council meeting. In this decision, the OSCE PC and the OSCE Secretariat have been tasked to strengthen dialogue on energy security, including all relevant actors in the field of energy such as producing, consuming and transit countries (http://www.osce.org/mc/23354?download=true, 1-2). Energy Security Dialogue takes the view that "energy security goes beyond security of supply to include security of demand and security of transit, as well as energy efficiency" (Rosner 2010: 3).

Promoting and strengthening energy security and finding acceptable solutions to the energy-related disputes at the global level require the effective use of all available dialogue opportunities on energy security. In the maintenance of a close and effective dialogue on energy security, the OSCE, as the largest regional security organization, can provide a platform for dialogue on energy security (http://www.osce.org/eea/45052). Rosner states that the OSCE covers "main energy producers and exporters, world's largest energy consuming countries and key transit States having a strategic position for European energy supply". Hence, the OSCE is a unique regional security organization in Europe in terms of providing a dialogue platform on energy security "between energy producers, consumers and transit states" (Rosner 2010: 1). Furthermore, the OSCE can serve as a multilateral form for dialogue to enhance and improve regional co-operation in the field of energy security and contributing to the resolution of energy-related disputes between the participating States (http://www.osce.org/eea/71241).

According to Snoy, the main priority areas for the dialogue on energy security among the participating States can include developing new ways for the diversification of energy resources and energy supply routes; effectively addressing the issue of energy security through covering major energy producers, consumers and transit States within the OSCE region with a view to strengthening energy security; intensifying joint efforts for the protection of critical infrastructure against terrorist attacks; ensuring legal and regulatory framework for the necessary energy investments with the purpose of promoting stable and reliable energy supply; and using energy sources more effectively, at the same time, achieving environmental sustainability across the entire OSCE region (Snoy 2006: 292-294).

Wheeler, in his presentation titled as 'The OSCE and Energy Security', points out that the OSCE can share its expertise, experience and knowledge accumulated in the fields of good governance and 
transparency of energy sectors; environmentally friendly and sustainable energy resource and the protection of critical energy infrastructures (Wheeler, Presentation titled as 'The OSCE and Energy Security', Meetings of the Energy Efficiency 21 Programme titled as 'The OSCE and Sustainable Energy', 24 April 2012). Rosner states that one of the key areas where the OSCE can provide an added value to the energy field is to contribute to the efforts for protecting critical energy infrastructure which is very important in terms of promoting energy-supply security and maintaining global price stability. "Energy prices in a time of scarcity are particularly vulnerable to even small attacks on global energy supply visa-vis the infrastructure that transits it" (Rosner 2010: 1).

The OSCE adopts an approach that maintaining an effective dialogue and co-operation on energy security at international level is crucial in terms of promoting stable and reliable energy supply; finding lasting solutions to the energy-related problems; and finally facilitating the emergence of transparent and open energy sectors (http://www.osce.org/eea/71241). Hence, as Wheeler states, the Organization works in close co-operation with "specialized energy-related organizations and structures, including the Vienna Energy Club and organizations located outside of Vienna such as the Energy Charter Secretariat, the International Energy Agency (IEA), and UN Economic Commission for Europe Committee on Sustainable Energy (UNECE) as well as North Atlantic Treaty Organization (NATO)" (Wheeler, The OSCE and Energy Security, Meetings of the Energy Efficiency 21 Programme 'The OSCE and Sustainable Energy' 24 April 2012).

\section{Global Environmental Politics and Environmental Activities of the Organization for Security and Co-operation in Europe}

The implications of environmental problems have dramatically increased since the later 1960s. A broad range of environmental issues such as huge quantities of hazardous wastes, air pollution, acid rain, stratospheric ozone depletion, climate change, loss of biological diversity and global warming have emerged as major regional and global environmental problems. "Wide-spread industrialization and rapid population growth have greatly increased the scale and intensity of the over-exploitation of natural resources and environment degradation", which in turn led to the emergence of a broad range of serious regional and global environmental problems (Greene 2001: 452-453).

The impact of humanity on the environment has also dramatically increased since the 1960s. The increasing rates of human activities and efforts for increasing living standards and industrialization at the global 
level have resulted in environmental degradation and considerable change of the ecological system, generating a wide range of environmental problems such as global warming and climate change. Wide-spread industrialization trends and pursuing higher level for living standards have led to the tremendous exploitation of natural resources and substantially contaminated the environment (Soros 1999: 27).

The scale and intensity of the environmental problems have substantially expanded due to the wide-spread industrialization, rapid population growth and increased fuel consumption in the world since the 1960s. In these circumstances, it is generally agreed that "the environment can no longer be viewed as a relatively stable background factor". In addition to the existing environmental challenges, the second half of the twentieth century has witnessed the emergence of new global environmental problems (Hurrel and Kingbury 1992: 2-3).

Environmental issues and challenges were considered "as minor issues; marginal to core national interests and to international politics" by most states until the 1980s. However, environmental issues have gained "a much higher status in world politics" particularly after the end of the Cold War period. Growing international concern about the environment has emerged as a response to the fundamental alterations occurred in the ecological system since the 1980s. Because physical environment and human health started to be threatened by a wide range of factors such as "the release of ozone-destroying chemicals; emissions of sulfur and nitrogen oxides; the production of toxic chemicals and other hazardous wastes and their introduction into to air, water, and soil; and deforestation" (Chasek, Downie and Brown 2006: 1-2). As mentioned earlier, growing industrialization and urbanization and rapid population growth have brought about a profound effect in scale and intensity of the environmental problems and challenges (Chasek, Downie and Brown 2006: 11-12). Consequently, the major alterations in today's physical environment are mainly derived from the overwhelming economic activity and rapid population growth occurred during the second half of the twentieth century (Chasek, Downie and Brown 2006: 8-9).

In line with the increasing significance of environmental security problems, the OSCE has adopted a view that security, stability and health of individuals, societies and states within the OSCE region are being seriously threatened by the problems and challenges generating from environmental factors. In order to achieve sustainable economic growth and prosperity and social development, sustainable use and sound management of natural resources must be ensured. Recognizing the growing importance of this fact, the OSCE, through its environmental 
activities, aims at promoting peace, security and stability within its region (http://www.osce.org/secretariat/30348?download=true).

Within the framework outlined above, "recognizing the close connection between environmental issues and security", the OSCE performs a wide range of environmental activities aiming at "restoring and maintaining a sound ecological balance in the air, water and soil". The main priority areas for protecting and improving environment are to achieve "sustainable use and sound management of natural resources", particularly promoting an effective water resource management; prevent soil degradation; promoting the safely disposal of hazardous waste; provide support and assistance for the maintenance of energy security dialogue among the participating States; and finally supporting the full and effective implementation of the Energy and Security Initiative (ENVSEC). Furthermore, the OSCE has engaged in a range of initiatives focusing on raising the environmental awareness and encouraging public participation in environmental decision-making (http://www.osce.org/what/environmental).

In the field of climate change, the OSCE with the European Environment Agency as a partner has carried out a project entitled 'Security Implications of climate change'. This project is aimed at "developing scenarios for different OSCE regions to assess the impact of climate change on natural resources, energy and food availability, and their repercussions on security by 2050". In this respect, the OSCE has organized a number of scenario workshops in several OSCE participating States with a view to providing relevant tools for further possible cooperation and formulation of new policy recommendations which can be evaluated and implemented by the relevant OSCE bodies, structures and field missions (http://www.osce.org/eea/climatechange).

The OSCE has also carried out several projects regarding the hazardous waste management, particularly in the former Soviet Union republics with the purpose of assisting the participating States to enhance the ability of their border guards and customs officials in detecting and preventing the illegal trafficking of hazardous waste (http://www.osce.org/eea/43653 and http://www.osce.org/secretariat/30348?download=true).

The OSCE attaches a special importance to protecting and improving the sustainable water resources. Hence, the Organization has been engaged in several activities aiming at achieving effective water management in its region. Water scarcity and water-related disputes sometimes pose a serious threat and challenge to regional and international security. Water 
is used for different purposes by countries. "Downstream countries are affected by the activities of the upstream countries related to the quantity or quality of water. Excessive use of water by one country can lead to a decreasing supply of water to the neighboring state. Furthermore, pollution from one country may lead to the degradation of the water quality in another". Therefore, "governing water inevitably involves governing conflicting interests" between the interested states.

An effective water management requires well-established mechanisms in regulating and monitoring water resources. The lack of such mechanisms may lead to the emergence of water-related tensions and disputes and weaken the confidence between the neighboring countries. As the rivers in the OSCE region have a transboundary character, maintaining close and active co-operation on water resources is of great value for the neighboring countries. In this respect, the OSCE participating States are strongly convinced that achieving sound water management in a cooperative manner will absolutely contribute to the promotion of security, stability and peace among the neighboring countries sharing transboundary water resources. In this regard, the OCEEA focuses on encouraging co-operation on transboundary water management and developing legal and institutional frameworks among the riparian countries within the OSCE sub-regions.

Energy and Security (ENVSEC) Initiative serves a platform for dialogue and co-operation on environmental issues with a view to promoting security, stability, peace and sustainable economic and social development (http://www.osce.org/secretariat/30348?download=true). The ENVSEC Initiative works to prevent and decrease security risks and challenges derived from environmental factors. The Initiative aims to strengthen and enhance co-operation among and within States which might be subjected to environmental damage (http://www.osce.org/eea/43651).

The ENVSEC Initiative is composed of six key partner organizations, including the OSCE, United Nations Environment Programme (UNEP), United Nations Development Programme (UNDP), and United Nations Economic Commission for Europe (UNECE), the Regional Environment Centre for Central and Eastern Europe (REC), and finally the North Atlantic Treaty Organization (NATO) as an associated partner. The ENVSEC was chaired by the OSCE in 2011. During its Chairmanship of ENVSEC, the OSCE basically focused on strengthening "the security aspects of the Initiative and to renew the understanding of the environment and security linkages in the OSCE region". 
The ENVSEC focuses on four basic areas in its overall work: "fostering co-operation over shared natural resources, particularly transboundary water; contributing to the reduction of cross-border risks from hazardous substances and pollution; supporting improved urban development and adaptation to climate change; and finally fostering empowerment of civil society to address environment and security risks".

The ENVSEC assesses and addresses environmental problems and challenges in a particular region with the purpose of identifying the political, economic and social repercussions of these environmental problems which might include an impact on security (http://www.osce.org/eea/43651). ENVSEC carries out these assessment processes through working in close co-operation and consultation with the relevant governmental institutions, including the ministries of foreign affairs, defense and environment as well as civil society groups, experts, academia and local stakeholders (http://www.osce.org/eea/43651). ENVSEC produces reports as a result of assessments in order to understand "the linkages between environment and security in the political and socio-economic reality". The Initiative also aims at strengthening its capacity and improving its ability to provide more effective and better responds to emerging security risks and challenges generated from environmental issues Ronald A. Kingham 2011: 12-13)

In the field of environment, the OSCE assists the participating States to implement commitments, norms and principles. In this respect, the OSCE believes that "a well-informed and vigorous civil society" can play an important role in environmental decision-making. Therefore, the OSCE works to advance "understanding of environment and security linkages among the civil society" (http://www.osce.org/secretariat/30348?download=true). In this respect, the OSCE has designed a small grants programme titled as 'Civic Action for Security and Environment' (CASE) to "support civil society organizations in addressing environment and security challenges in cooperation with their governments". CASE serves as a tool to introduce a civil society perspective to the environment and security fields. The OSCE, through launching CASE, aims at strengthening "the capacity of civil society organizations to respond to the environment and security challenges facing their countries and to participate in environmental governance, which in turn contributes to increased public awareness on environmental issues" (http://www.osce.org/eea/72778). 


\section{The Evaluation of the Economic and Environmental Dimension of the Organization for Security and Co-operation in Europe}

Today, the OSCE region faces several economic and environmental problems and threats at different levels. The end of the Cold War period led to the beginning of the transition processes of the former socialist countries towards market economy in Europe. The States in economic transition intensified their efforts to reform their economic policies, structures and institutions with the purpose of opening their national economies to international trade and investment which in turn could promote economic growth and development. While some OSCE participating States have been successful in transforming their economies according to the market economy principles, other participating States could not complete their economic reform process. The European Union membership perspective has enabled some OSCE participating States to undertake economic reform measures. The EU has also provided financial and technical assistance to the transition countries for the full and effective implementation of the economic reform decisions as well as meeting the EU standards for the full membership. As a result, growing disparities have emerged between the OSCE participating States which in turn seriously weakens social and economic stability within the OSCE region (Fonblanque 2005: 181).

After the CSCE transformed into a regional security organization called as the 'OSCE' after the end of the Cold War era, the Organization has engaged in a wide range of activities with a view to support its participating States' efforts towards liberal market economy principles. However, several OSCE participating States have highly criticized the Organization's visibility and impact on the economic and environmental dimension. Nearly all participating States accept that "the OSCE is not an economic, financial, or donor organization, and that this limits its activities in the second dimension from the outset" (Evers, Kahl and Zellner 2005: 29). Most participating States do not consider the OSCE as an organization to act in the field of economy and environment. Additionally, it is obvious that the OSCE does not have adequate economic capabilities and resources ('Common Purpose Towards a More Effective OSCE - Final Report and Recommendations of the Panel of Eminent Persons On Strengthening the Effectiveness of the OSCE', 27 June 2005: 15). Wohlfeld states that the economic and environmental dimension of the OSCE is both under-funded and underdeveloped (Wohlfeld 2008: 649). Notwithstanding, the participating States assert that the OSCE has neglected the economic and environmental dimension 
in favor of politico-military and human dimensions. It is claimed that the Organization does not tend to use all available resources and opportunities for the economic and environmental activities (Evers, Kahl and Zellner 2005: 29).

The OSCE participating States agree that economic and environmental challenges and threats include direct and damaging effects on security. They are also convinced that economic and environmental dimension should be taken into account more seriously. However, it seems that the second dimension does not constitute a priority area for the participating States within the OSCE framework (Interview with Mid-level Government Official 3, Permanent Mission of Turkey to the OSCE, Vienna, 19 October 2012).

Fonblanque points out that the OSCE has failed in bringing out tangible resolutions for the economic and environmental problems and challenges, facing the participating States. The economic and environmental activities have been mostly carried out through implementation meetings, some specific conferences and seminars as well as small-scale projects. There is no doubt that all these activities are useful and they can also play an important role in raising the awareness of the economic and environmental issues. However, these activities can just only provide a marginal contribution to addressing the risks, threats and challenges to security generating from economic and environmental matters. The OSCE could not develop operational capabilities for the economic and environmental issues (Fonblanque, 2005: 180-181). As a result, the OSCE is still far from creating a real difference on the ground in relation to economic and environmental problems (Oberschmidt and Zellner 2001: 19).

Buttanri asserts that economic and environmental dimension can be evaluated as the less effective dimension of the OSCE. The main reason for this is that there is no consensus among the participating States with regard to the OSCE's involvement in economic and environmental issues. While some participating States tend to establish a close link between economic-environmental matters and security, others are not in favor of bringing economic and environmental matters into the OSCE agenda. In other words, there are ongoing debates on which issues the OSCE should become engaged in the economic and environmental dimension. Some participating States assert that there are also some specialized organizations and institutions engaged in economic and environmental issues within the OSCE region. Therefore, the OSCE should not involve in economic and environmental-based issues dealt with by other organizations. Additionally, financial resources and staff allowed to the 
economic and environmental dimension within the OSCE context are inadequate. There is no institutional structure or autonomous institution for the economic and environmental dimension like the Office for Democratic Institutions and Human Rights (ODIHR), the High Commissioner on National Minorities (HCNM) or the Representative on the Freedom of the Media (RFM). The mandates of the OSCE field missions on economic and environmental issues are also so weak (Interview with Esra Buttanri, Environmental Affairs Adviser, Office of the Co-ordinator of OSCE Economic and Environmental Activities, Vienna, 14 November 2012).

Cottey argues that although the OSCE adopts a comprehensive security approach, the Organization's role in addressing economic and environmental aspects of security has been limited in practice. When considering the impact of the OSCE in the economic and environmental dimension, it can be said that "the Organization's commitment to comprehensive security remains at "rhetorical level than substantive" due to the imbalanced development of the OSCE's activities over three dimensions of security, namely politico-military, economicenvironmental and human dimensions (Cottey 2002: 51-54).

Reuchlin asserts that "as a part of its comprehensive approach to security, participating States have to struggle to turn the OSCE's rhetoric for the second dimension into a reality" (Reuchlin 2007: 64). Fonblanque argues that "transformation of the economic and environmental dimension to focus on assisting States to overcome their economic and environmental problems would meet a real need." (Fonblanque 2005: 182-183). Reuchlin states that the OSCE needs substantial improvements in dealing with the economic and environmental problems of the participating States which may have destabilizing effects on security and stability. However, most importantly, "what the economic and environmental dimension ultimately needs is more political will and a strategic vision on behalf of the participating States to whole-heartedly embrace the concept of comprehensive security" (Reuchlin 2007: 75-76).

As a result, although the OSCE has tried to contribute to security and stability in its region through its economic and environmental activities, it is commonly agreed that the Organization has failed to acquire substantial results in its second dimension. That is why some OSCE participating States have made sharp criticisms with regard to the OSCE's performance on the economic and environmental dimension.

\section{Conclusion}


This article has focused on the economic and environmental dimension of the OSCE. The OSCE always engages with economic and environmental issues as an integral component of the Organization's comprehensive approach to security. In this context, it can be said that the OSCE has been successful in bringing economic and environmental concerns to the security agenda, particularly through monitoring and reviewing effectively the developments in the economic and environmental fields within its region.

The OSCE has established an understanding that close and effective cooperation and co-ordination on economic and environmental matters can make a valuable contribution to improving security, stability and prosperity throughout the whole OSCE region. In this regard, the OSCE also provides a platform for co-operation on economic and environmental issues through common instruments. The OSCE mainly tries to deal with the economic and environmental issues which may have negative implications on security within the participating States.

The OSCE produced two milestone documents, namely Bonn Document and Maastricht Strategy Document for the Economic and Environmental Dimension, which have shaped the economic and environmental attention of the Organization. These two documents established basic commitments, identified main objectives and indicated threats in the field of economic and environmental dimension. The OSCE also developed a number of structures and instruments, focusing on the economic and environmental dimension with the purpose of addressing threats and challenges generating from economic and environmental domains.

Although the OSCE's involvement in the economic and environmental dimension reflects the Organization's comprehensive approach to security, this article argues that economic and environmental dimension turns out to be the weakest dimension of the OSCE in terms of the overall contribution of the Organization to achieving comprehensive security. In other words, economic and environmental matters have remained secondary in comparison to the non-military issues in the field of human dimension and non-military aspects of the politico-military dimension within the OSCE context. In this farmework, it can be argued that the impact of the OSCE's economic and environmental dimension has been considerably limited in operational terms. The OSCE is far from finding concrete solutions for the participating States' economic and environmental-based problems and preventing their negative effects on the security of its participating States. The OSCE's activities in the economic and environmental dimension have been distinctly restricted to raising the awareness on economic and environmental issues which can 
have destabilizing effects on security; organizing meetings for the reviewing of the implementation of the commitments by the participating States; and encouraging the participating States to intensify their efforts for co-operation on economic and environmental issues.

\section{References}

Brichambaut, Marc Perrin de (2007), "The OSCE and the $21^{\text {st }}$ Century". Helsinki Monitor: Security and Human Rights No.3: 180-187.

Buzan, Barry; Wæver, Ole; and Wilde, Jaap de (1998). Security: a new framework for analysis. Boulder, Colo.: Lynne Rienner Pub.

Chasek, Pamela S.; Downie, David L.; and Brown Janet Welsh (2006). Global Environmental Politics. Colorado: Westview Press.

Cottey, Andrew (2002). “The OSCE: Crowning Jewel or Talking Shop?”. Uncertain Europe: Building a New European Security Order?. in Martin A. Smith and Graham Timmins (eds). London: Routledge. 43-61.

Evers, Frank (2010). "Balancing by Cross-Linking Renewed Dialogue on the OSCE Economic and Environmental Dimension". Center for OSCE Research (CORE) Working Paper 21.

Evers, Frank; Kahl, Martin; and Zellner, Wolfgang (2005). "The Culture of Dialogue The OSCE Acquis 30 Years after Helsinki". Center for OSCE Research (CORE). Vienna.

Fonblanque, John de (2005). "Strengthening the economic and environmental dimension of the OSCE (EED)". Helsinki Monitor No.3: 180-183.

Gärtner, Heinz and Hyde-Price, Adrian (2001). "Introduction”. Europe's New Security Challenges. in Heinz Gärtner, Adrian Hyde-Price, and Erich Reiter (eds). London: Lynne Rienner Publishers. 1-23.

Greene, Owen (2001). "Environmental Issues". Globalization of World Politics. in John Baylis and Steve Smith (eds). Oxford: Oxford University Press. 385-413.

Hurrel, Andrew and Kingbury, Benedict (1992). "The International Politics of the Environment: An Introduction". The International Politics of the Environment. in Andrew Hurrel and Benedict Kingsbury (eds). Oxford: Clarendon Press. 1992.

Kingham, Ronald A. (2011).'Discussion Paper on Economic and Environmental Confidence-and Peace-building Measures and the 
Role of the OSCE". Institute for Environmental Security, For the OSCE Chairmanship Workshop on Economic and Environmental Activities as Confidence Building Measures. Vienna.

Mérand, Frédéric; Irondelle, Bastien; and Foucault, Martial (2011). "Theorizing the change in the European Security Environment". European Security since the Fall of the Berlin Wall. in Frédéric Mérand, Martial Foucault, and Bastien Irondelle (eds). Toronto: University of Toronto Press. 1-22.

Oberschmidt, Randolf and Zellner, Wolfgang (2001). "OSCE At the Crossroads". Institute for Peace Research and Security PolicyCenter for OSCE Research (CORE). Working Paper 2. Hamburg.

Reuchlin, Philip (2007). "Environmental security: ways ahead for the OSCE". Helsinki Monitor: Security and Human Rights No.1. 6476.

Rosner, Kevin (2010). "How the OSCE Can Contribute to Energy Security”. Journal of Energy Security.

Snoy, Bernard (2006). "Energy Security: An OSCE perspective". Helsinki Monitor No.4. 291-294.

Soroos, Marvin S. (1999). "Global Institutions and the Environment: An Evolutionary Perspective". The Global Environment Institutions, Law, and Policy. in Norman J. Vig and Regina S. Axelrod (eds). Washington, D.C.: CQ Press. 27-51.

Wheeler, Richard (2012). "The OSCE and Energy Security, Meetings of the Energy Efficiency 21 Programme: The OSCE and Sustainable Energy" (Presentation). Geneva. Energy Security-OSCE general mandate, CEIP, economic and geo-political, legal dimensions.

Williams, Paul D. (2013). "Security Studies: An Introduction”. Security Studies: An Introduction. in Paul D. Williams (ed). London and New York: Routledge. 1-12.

Wohlfeld, Monika (2008). "Reconceptualization of Security in the CSCE and OSCE". Globalization and Environmental Challenges Hexagon Series on Human and Environmental Security and PeaceVol.3 Part VII. 643-650.

"The OSCE Concept of Comprehensive and Co-operative Security An Overview of Major Milestones". OSCE Secretariat Conflict Prevention Centre Operations Service. Vienna. June 2009. 
"Common Purpose Towards a More Effective OSCE - Final Report and Recommendations of the Panel of Eminent Persons On Strengthening the Effectiveness of the OSCE”. 27 June 2005.

"Document of the Bonn Conference on Economic Co-operation in Europe". Bonn. 1990.

"OSCE Strategy to Address Threats to Security and Stability in the 21st Century”. OSCE Ministerial Council Maastricht 2003.

Interview with Mid-level Government Official 3. Permanent Mission of Turkey to the OSCE. Vienna. 19 October 2012.

Interview with Esra Buttanri. Environmental Affairs Adviser. Office of the Co-ordinator of OSCE Economic and Environmental Activities. Vienna. 14 November 2012.

Interview with Richard Wheeler. Senior Programme Officer. Energy Security. Office of the Co-ordinator of OSCE Economic and Environmental Activities. Vienna. 14 November 2012.

OSCE, 'Economic and Environmental Sub-Committee', available at http://www.osce.org/eea/13910?download=true, Accessed on 20 November 2013.

OSCE-, 'Energy Security Dialogue', available at http://www.osce.org/eea/45052, Accessed on 24 August 2014.

OSCE, 'Factsheet of the Office of the Co-ordinator of OSCE Economic and Environmental Activities, OSCE Economic and Environmental Dimension', (20 February 2012), available at http://www.osce.org/secretariat/30348?download=true, Accessed on 10 November 2013.

OSCE, 'OSCE-Secretariat - Office of the Co-ordinator of OSCE Economic and Environmental Activities', available at http://www.osce.org/eea, Accessed on 10 November 2013.

OSCE, OSCE States Review Implementation of Economic and Environmental Commitments', available at http://www.osce.org/eea/96420, Accessed on 15 November 2013.

OSCE, 'Economic Activities', available at http://www.osce.org/what/economic, Accessed on 15 November 2013. 
OSCE, 'Environmental Activities', available at http://www.osce.org/what/environmental, Accessed on 15 November 2013.

OSCE, 'OSCE Strategy Document for the Economic and Environmental Dimension', OSCE Ministerial Council, Maastricht 2003, (2 December 2003), available at http://www.osce.org/eea/20705?download=true, Accessed on 20 November 2013.

OSCE, 'OSCE Secretariat, OCEEA, Activities, Economic and Environmental Forum', available at http://wwwold.osce.org/eea/43229, Accessed on 20 November 2013.

OSCE, 'OSCE Meeting in Vienna to Discuss Implementation of Commitments, Future Priorities in Economic and Environmental Dimension', (17 October 2011), available at http://www.osce.org/eea/84019, Accessed on 20 November 2013.

OSCE, 'Economic Activities', available at http://www.osce.org/what/economic, Accessed on 1 December 2013.

OSCE, 'OSCE Special Expert Meeting, Vilnius (13-14 September 2010) Factsheet', available at www.osce.org/eea/71241, Accessed on 10 December 2013.

OSCE, 'OSCE Mission to Serbia and Montenegro, Renewable Energy for Energy Security', available at http://osce.org/serbia/16332, Accessed on 5 December 2013.

OSCE, 'OSCE Ministerial Council Brussels 2006, Decision No.12/06 on Energy Security Dialogue in the OSCE', available at http://www.osce.org/mc/23354?download=true, Accessed on 5 December 2013.

OSCE, 'Security Implications of Climate Change', available at http://www.osce.org/eea/climatechange, Accessed on 26 December 2013.

OSCE, 'Hazardous Waste', available at ttp://www.osce.org/eea/43653, Accessed on 26 December 2013.

OSCE, 'ENVSEC Initiative', available at http://www.osce.org/eea/43651, Accessed on 27 December 2013.

OSCE, 'Civic Action for Security \& Environment', available at http://www.osce.org/eea/72778, Accessed on 28 August 2014. 
OSCE, 'Secretariat-Office of the Co-ordinator of OSCE Economic and Environmental Activities, Overview', available at http:/osce.org/eea/43176, Accessed on 15 November 2013.

OSCE, '2012 OSCE Economic and Environmental Dimension Implementation Meeting, available at http://www.osce.org/eea/96401, Accessed on 20 November 2013. 
